\author{
Mirosław Wincenciak \\ University of Bialystok, Poland \\ ORCID: 0000-0003-3099-1012 \\ m.wincenciak@uwb.edu.pl
}

\title{
"Transformation" of a Tax and Customs Administration Officer's Service Relationship into an Employment Relationship
}

\author{
"Przekształcenie" stosunku służbowego funkcjonariusza \\ administracji celno-skarbowej w stosunek pracy
}

\section{SUMMARY}

Lack of court protection for officers whose current service relationship is substituted with a form that is less beneficial - an employment relationship, should be seen as a violation of their right to trial. A labour court, by definition, is not an appropriate court when it comes to cases of entering into or the termination of service relationships having a legal and administrative character. This court can judge cases concerning the employment relationship of an employee but fundamentally does not have jurisdiction to assess the establishment and termination of a legal and administrative relationship. Therefore, sending customs officers to labour courts causes the transformation of a service relationship into an employment relationship to slip out of court control.

Keywords: service relationship of uniformed services officers

\section{THE ESSENCE OF A SERVICE RELATIONSHIP OF UNIFORMED SERVICE OFFICERS}

During the Second Polish Republic, both the service relationships of professional soldiers as well as civil service officers were considered to be a part of administrative law ${ }^{1}$. Currently, there is no doubt that administrative and legal service

1 T. Zieliński, Podstawowe problemy prawa stużby państwowej, „Państwo i Prawo” 1982, z. 9, p. 55; W. Jaśkiewicz, Pracownicy administracji, [in:] System Prawa Administracyjnego, red. J. Jendrośka, t. 2, Wrocław 1977, pp. 380-382. 
relationships are a part of public law. It is indicated that the essence of a service relationship, a type of a legal relationship occurring between particular entities, is regulated by the provisions of public (administrative) law and labour law ${ }^{2}$. Elements that are characteristic to the essence of a service relationship, other than the broad catalogue of responsibilities, include more stringent criteria of legal capability for employment, one-sided statutory determination by the state of service conditions, chain of command, intensified system of responsibility and special rights which are not present in the area of contractual employment relationships ${ }^{3}$.

Differentiation of the two concepts - a service relationship and an employment relationship - requires the consideration of the legal bond through which the service (work) is performed as well as its structure and elements. Service relationships can be divided into two basic groups. The first consists of service relationships constraining military uniformed services. The second includes employment service relationships ${ }^{4}$. Case law of the Constitutional Tribunal maintains the opinion that service relationships of uniformed service officers are classified as administrative and legal relationships ${ }^{5}$. Doctrine also indicates that these relationships fall into this category $^{6}$ since the legal status of officers of these services is established one-sidededly and the rights and responsibilities within the scope of these relationships are defined in the regulations normalizing service relationships?

It must be indicated that the dual relation of these officers is the result of the hierarchal character of military formations ${ }^{8}$. A service relation is characterised by the fact that people serving within a militarised formation are subordinate to their superior officers who give them orders and commands. The essence of performing duties resulting from a service relationship within militarised formations is the insurance of national security. Operations of uniformed services can be especially

2 T. Kuczyński, Pojęcie i przedmiot prawa stosunków stużbowych, [in:] System Prawa Administracyjnego, t. 11: Stosunek stużbowy, red. R. Hauser, Z. Niewiadomski, A. Wróbel, Warszawa 2011, p. 7.

3 Ibidem, p. 11.

4 Ibidem, p. 13.

5 Cf. judgement of the Constitutional Tribunal of 14 December 1999, SK 14/98, OTK ZU 1999, No. 7, item 163; judgement of the Constitutional Tribunal of 27 January 2003, SK 27/02, OTK ZU 2003, No. 1A, item 2; judgement of the Constitutional Tribunal of 19 October 2004, K 1/04, OTK ZU 2004, No. 9A, item 93.

6 According to M. Wieczorek (Charakter prawny stosunków stużbowych funkcjonariuszy stużb mundurowych, Torun 2017, p. 297) a service relationship is a type of a legal and administrative relationship. Cf. T. Kuczyński, Pojęcie i przedmiot prawa..., p. 3 ff. as well as presented within it review of positions.

7 P. Szustakiewicz, Stosunki stużbowe funkcjonariuszy stu̇̇b mundurowych i żołnierzy zawodowych jako sprawa administracyjna, Warszawa 2012, pp. 48-49; T. Kuczyński, Właściwość sąu administracyjnego w sprawach stosunków stużbowych, Wrocław 2002, pp. 50-55.

8 S. Pieprzny, Organy bezpieczeństwa i porzadku publicznego w prawie administracyjnym, Rzeszów 2007, p. 149. 
bothersome for citizens. Officers of uniformed services and professional soldiers bear disciplinary responsibility justified by the social role of these formations as well as the character of tasks and competencies they are given ${ }^{9}$.

Performance of services as part of militarised formations is connected with prohibitions and limitations occurring to a greater degree than in other employment relationships. Regulations stipulate inability to belong to a political party, limit the scope of union activity and membership in certain organizations as well as prohibit or restrict additional business activity ${ }^{10}$.

Additionally, service relationships are also characterised by the employer's ability to transfer an officer so that his service is performed in a different place. Monetary remuneration for service is defined as a commission rather than a salary $^{11}$. Other than their commission officers of the military and other services are also entitled to allowances ${ }^{12}$. A special right resulting from the need for an officer to be available is his entitlement to living quarters at or near the place in which he or she has been stationed during service ${ }^{13}$.

A service relationship of an officer also contains the concept of fastness which is interpreted as his inability to terminate his service relationship by giving notice as stipulated by the regulations of the Labour Code as well as a finite statutory catalogue of reasons for the termination of an officer's service ${ }^{14}$. Additionally, the administrative and legal character of a service relationship also implies that the establishment and the termination of that service relationship occurs as an administrative act.

The aim of the present article is an attempt to assess the regulations contained within the Act of 16 November 2016 - Provisions Introducing the Act on the National Tax Administration ${ }^{15}$, which contains distinctive features in respect to the termination of a service relationship of a customs officer. One of the constructions included in this Act, consistent with the case-law of administrative courts, provides for the termination of a service relationship and the initiation of an employment relationship as a result of the officer's acceptance of an offer for employment. The assessment of this regulation is fundamentally needed for two reasons: 1) it seems

${ }^{9}$ P. Szustakiewicz, op. cit., pp. 250-251.

${ }^{10}$ M. Wieczorek, op. cit., p. $315 \mathrm{ff}$.

${ }^{11}$ Cf., for example, Article 100 of the Police Act: "A police officer's commission consists of basic commision and allowances to that commission".

${ }_{12}$ Cf., for example, Article 87 (1) of the National Fire Department Act which states that firemen get the following allowances to their commission: 1) rank allowance; 2) service allowance; 2a) motivational allowance; 4) allowances for special skills, qualifications, conditions or place of service.

${ }_{13} \mathrm{Cf}$., for example, Article 88 (1) of the Police Act, according to which a full time police officer has the right to living quarters in or near a town or city where he or she is serving with consideration to the number of family members and their rights resulting from other laws.

${ }_{14}$ M. Wieczorek, op. cit., p. 336.

15 Journal of Laws, item 1948 as amended, hereinafter: NTAA. 
that the accepted legal solution according to the interpretation of administrative courts mentioned above contradicts the up-to-now legislative practice within the scope of the legal form of terminating a service relationship - since an administrative and legal relation is terminated as a result of the acceptance of an offer of employment and not as an effect of an administrative act; and 2) the accepted manner of interpretation, in my opinion, will deprive any officer whose service relationship has been changed to an employment relationship of his right to a fair trial.

\section{CHANGES IN EMPLOYMENT CONNECTED TO THE REFORM OF THE TAX AND CUSTOMS ADMINISTRATION}

The nature of the reform of the tax and customs services engaged in the gathering of budget revenue as part of a governmental administration, realised by the legislator by means of the Act of 16 November 2016 on the National Revenue Administration ${ }^{16}$ and the NTAA was to consist, among others, on the consolidation of tasks and competencies of services as well as on limiting the number of officers performing their duties as part of a service relationship. Regulations reforming the customs and revenue administration system implement temporary solutions concerning the status of current officers of services being decommissioned. In accordance with Article 165 (3) NTAA, for a transitional period lasting until 31 May 2017, the legislator ordered governing bodies to observe the rule of maintaining the service continuity of officers of individual services. Pursuant to this regulation customs officers serving in customs chambers or in facilities of the organ supporting the minister competent for public finances became, on the day the Act on the National Revenue Administration became binding, i.e. on 1 March 2017, officers of the Customs Revenue Service. On the basis of NTAA regulations, it is possible to specify the following regulations concerning the service relationship of officers.

The first solution foresees the continued maintenance of the transformed through Article 165 (3) NTAA service relationship with an officer occurring by providing him with a proposal to continue service. An officer who received a proposal to serve in the Customs Revenue Service maintained service continuity and was entitled to receive a rank that was equal to one currently held. The proposal for service in understanding of Article 169 (4) NTAA occurs as an administrative decision. Issuing such a decision, the Director of a Customs Chamber should take into account the officer's qualifications and career progression as well as his current place of residence (Article 165 (7) NTAA). The officer has the right to question new conditions of service by filing a petition to have his case reviewed and then by filing a court administrative complaint (Article 169 (4) and (7) NTAA). He can

\footnotetext{
${ }^{16}$ Journal of Laws, item 1947.
} 
also file, within an allotted time period, a statement of refusing the proposal of service which results in the termination of a service relationship (Article 170 (1) (2) and Article 170 (2) NTAA).

A second solution, provided within the Act which could be used in regard to current officers, was to have their service relationship expire which should be treated as a termination of service. Termination of service through the expiration of a service relationship took place when no proposal of any relationship, neither service nor employment, was made to an officer (the organ remained passive) or through his refusal of the proposal for either employment or further service. This solution is stipulated in Article 170 (1) NTAA which states that service relationships of people serving in units of the National Tax Administration expire: 1) on 31 August of 2017 if these people, until 31 May 2017, do not receive a written proposal defining new terms of employment or service; 2 ) after the passing of 3 months, counting from the month occurring after the month in which the employee or officer filed a statement refusing the proposal for employment or service, but no later than 31 August 2017. Regulations obligating organs to treat the expiration of a service relationship as a termination of service are contained in Article 170 (4) NTAA.

A third option, one that will be discussed later on, is the transformation of a service relationship into an employment relationship when a current officer received a proposal for employment and accepted it (Article 165 (7) in conjunction with Article 170 (2) NTAA).

\section{"TRANSFORMATION" OF A SERVICE RELATIONSHIP INTO AN EMPLOYMENT RELATIONSHIP}

In the regulations of Article 171 (1) NTAA it has been stipulated that the transformation of a service relationship into an employment relationship occurs as a result of the acceptance of a proposal for employment. The concept of the transformation of a service relationship is not defined in the above-mentioned legal acts. The stipulated regulation is interpreted that as a result of the transformation of a service relationship into an employment relationship there occurs an expiration of an officer's service relationship. This consequence is not directly articulated by the Act. The expiration which is the result of the transformation bears the same consequences as expiration defined in Article 170 (1) (1) and (2) NTAA. Therefore, the regulations of Article 170 (3) NTAA stipulating that the expiration of a service relationship is treated as termination of service relates to the expiry that is the result of transformation despite a lack of a literal reference to pertinent law. In one of the judgements of the Supreme Administrative Court, it has been ascertained that since the "transformation" of a relationship changes the legal relationship which previously was defined as a service relationship created 
on a basis of an administrative decision then the issue of an administrative act is also necessary to terminate it. Issuance of such an administrative act allows the control of administrative activities and, at the same time, prevents arbitrary assessment of an officer by his superiors ${ }^{17}$. I believe this opinion to be correct, however, currently, decisions contrary to its spirit dominate ${ }^{18}$. For a long time now, within the doctrine of administrative law as well as in judicature, there has been expressed a stance according to which settlement of matters through an administrative decision should be done not only in cases directly stipulated by the legislator but also in situations where within the object and content of the regulation it is possible to interpret an obligation of an organ to act with authority through issuing an administrative decision ${ }^{19}$. Regulations of substantive law not only directly foresee a way to settle a particular matter through an administrative decision but also do so through the verbal description of the authority's power to settle a case (such as permits, allocates, decides).

An externally directed authoritative administrative act is founded on an exact statutory authorisation. It means the application of a complete substantive norm that determines all elements of the administrative and legal relationship, including the competence (ability, capability) of a public administration body to apply a specific legal norm ${ }^{20}$. A public administration organ does not have a general competence to act authoritatively and its every action must have an exact legal basis (norms specifying the legal forms that an administrative body may use). For this reason, the possibility of giving a general authorisation to an organ to act within a particular sphere or in a respective manner has been criticized many times within literature. It is assumed that in these types of externally directed activities of a body general authorisation is not sufficient $t^{21}$. However, since in the case of customs officers the initiation of a service relationship was done through an administrative act than the assumption of a position regarding the existence of authorisation to issue an administrative act dissolving or terminating a service relationship reflects, to some extent, competencies to issue an administrative decision regarding the establishment of such a relationship. The presented regu-

${ }^{17}$ Cf. judgement of the Supreme Administrative Court of 8 February 2019, I OSK 1744/18.

${ }^{18}$ Cf. resolution of the seven judges of the Supreme Administrative Court of 1 Jyly 2017, I OPS $1 / 19$.

19 J. Zimmermann, Polska jurysdykcja administracyjna, Warszawa 1996, pp. 138-140; judgement of the Supreme Administrative Court in Wrocław of 31 August 1984, SA/Wr 430/84, OSP 1986, No. 9-10, item 176; B. Adamiak, Zagadnienie domniemania formy decyzji administracyjnej, [in:] Podmioty administracji publicznej i prawne formy ich działania. Studia i materiaty z Konferencji Naukowej poświęconej Jubileuszowi 80-tych urodzin Profesora Eugeniusza Ochendowskiego, Toruń 2005, pp. 17-18.

20 T. Kiełkowski, Sprawa administracyjna, Kraków 2004, pp. 36-38.

${ }^{21}$ J. Borkowski, Zagadnienie kompetencji ogólnej i szczegółowej, „Studia Prawnicze” 1971, nr 31, p. 75. 
lation of NTAA does not provide for ex lege "transformation" of all relations into employment relations. As I have already mentioned, the legislator differentiates the employment status of current officers into: service relations and employment relations, and also allows the possibility of not presenting either a job offer or a service offer. Allowing differentiation of the status of current officers, from the point of view of the assumptions of the customs and tax administration reform, is understandable. This differentiation, however, requires defining the differentiation criteria and presenting them in the act changing the employment status of the current officer. Thus, since the law of the NTAA permits the employment status of existing officers whose employment relationship was established on the basis of an administrative act to be differentiated, its cessation, or the "modification" requires the issuing of an administrative act. Since the employment relationship has not ceased ex lege, its termination requires the issue of an administrative act. The interpretation according to which the "transformation" of the service relationship, shaped on the basis of an administrative act, occurs by submitting a job offer to the current officer, cannot be considered correct. This would mean that the administrative relationship ceases as a result of a concerted declaration of intentions by the parties, i.e. on the basis of a legal act applicable to private law. The legal relationship formed by means of an administrative decision should be changed or terminated on the basis of an administrative decision. The administrative decision issued is in legal circulation until it is eliminated from legal circulation in the procedure provided for by the administrative body or administrative court.

It is clear that the norms of substantive law regulate the content and form of performing public administration. It is the regulations of substantive law that determine the type of solution used to decide an administrative matter. Doctrine indicates that forms of public administration activities have, as it were, a serving function in relation to the subject and scope of regulations expressed through norms of administrative law. Using various legislative techniques the legislator determines forms of authoritative realisation of those norms. The legislator, e.g., simply establishes that a determination of an administrative matter occurs in the form of an administrative decision or does not specify the form in which a particular matter should be settled and just generally stipulates that a given subject matter is subject to the regulations of the Administrative Procedure Code or does not regulate those issues at all. In respect to that last instance, it is the doctrine and the case-law that gain the responsibility to determine the type of matter at hand and which legal instruments are appropriate for its settlement in accordance with the law. This has been addressed by the Constitutional Tribunal which stated:

[...] if [...] there exist doubts as to the form of settling an administrative matter it should be assumed that a public administration organ is the right body to settle an existing administrative matter. It cannot happen that the regulations of law stipulate the attributes of a public administrative body 
for the solution of a defined category of administrative matters and these types of matters could not be settled only because the legislator did not clearly stipulate the form for settling them ${ }^{22}$.

At the stage of applying the law, whenever it is not clear and there exist numerous doubts as to its interpretation, Article 2 of the Constitution of the Republic of Poland, which states that "the Republic of Poland is a democratic legal state implementing the rules of social justice", is fundamental. On the basis of this rule legal doctrine asserts that:

[...] the individual's right to a fair trial, whose essence consists of granting that individual the right to defend his legal interests through proceedings normalized by legal regulations with a guaranteed right to be heard and active participation in establishing the facts, is fundamental in the shaping of the rights of an individual in respect to administrative proceedings ${ }^{23}$.

It should also be noted that contemporary conceptions of interpreting the law concerning so-called difficult cases make use of the broad understanding of the interpretation of law. Within this understanding, interpretation encompasses not only the process of determining the meaning of a legal regulation including a certain sequence of legal thought aimed at removing the ambiguities of a legal text. Interpretation of law should be understood as a process of constructing a legal norm from elements contained within various legal regulations ${ }^{24}$. Often, interpretation of the law is neither the creation of a norm from legal regulation or the determination of its objective meaning possessed by a given legal regulation nor removal of ambiguities in line with the motto interpretetio cessat in claris. Interpretation of law in the understanding described above is inevitably a creative process which does not, however, lead to the undermining of the state with the fundamental constitutional rule of power division ${ }^{25}$.

Since the act allows the customs and revenue administration to differentiate the legal situation of current officers and foresees three ways in which their relationships can be transformed: into employment relationships, continuation of a service relationship or not presenting them with any offer of employment, then it seems obvious that in all of the events mentioned above and every case changing the status of a customs officer requires the issuing of an administrative decision. The

${ }^{22}$ Judgement of the Constitutional Tribunal of 14 June 2005, P 18/03, OTK ZU 2005, No. 6A, item 63.

${ }^{23}$ B. Adamiak, op. cit., pp. 15-16.

${ }^{24}$ W. Jakimowicz, Wykładnia w prawie administracyjnym, Kraków 2006, passim.

${ }^{25}$ This indicates that during times of too-numerous laws its interpretation is not a process connected to the rule of minimizing interpretational activities but rather the understanding which resembles the building of a wall by adding on subsequent bricks or blocks - cf. dissenting opinion of judge T. Stawecki to the judgement of a Voivodeship Administrative Court in Warsaw of 5 December 2017, VII SA/Wa 2741/16. 
role of doctrine is to point out to the legislator systematically appropriate solutions that are compliant with the principle of a democratic state ruled by law. Judicature, in turn, can correct any discovered mistakes made by the legislator through pro-constitutional interpretation within the acceptable, so-called language-related interpretation of phrases or expressions ${ }^{26}$.

An officer who has lost his current status through becoming an employee has the right to know the causes for the termination of his service relationship. A body should prove, keeping in mind the qualifications possessed by that officer, the course of his service as well as his current and past places of residence, that those officers who have received offers to have their service relationships extended were better than the passed-over officer. Only the issuance of an administrative decision which should show causes for the selection of a particular statutory solution regarding a specified officer (an offer of employment rather than continuation of service) guarantees the possibility for performing a court assessment whether the organ, in accordance with the premises of law and not in a matter that was discretionary or arbitrary, differentiated the legal situation of customs and revenue service officers within the context of the principle of equal access to public service.

The constitutional order to respect the rule that everyone's right to public service should be equal implies transparency of rules and criteria which are applied to people attempting to become public servants. Lack of appropriate control and of procedures for appeal, and through that to due legal process, can be a significant barrier to respecting the above-mentioned rules, and will, therefore, violate the constitutional requirement of treating those attempting to become public servants equally.

As has been mentioned above the essence of a service relationship is that it expresses a legal relationship regulated through the regulations of public (administrative) law with prevalence of authoritative elements. The employing entity is not a particular administrative unit where the officer serves but the state as a whole. The state in the form of defined organizational structures and appropriate superior bodies representing them manintains authority over the officer where its most far-reaching manifestation is so-called increased availability. The legal status of an officer is determined through regulations that are mandatory in character. Decisions issued by the Constitutional Tribunal draw attention to the fact that matters regarding service subordination within the internal scope of the state and those concerning the service relationship in which the individual, in defense of his rights defining the essence of that relationship, questions the organ as a separate subject with rights and responsibilities. Undoubtedly claims resulting from the circumstances of the officer accepting an offer for employment and the termination of a service relationship are beyond the scope of internal service subordination between a superior officer and a subordinate mentioned in Article 5 (2) of the Act of 30 August

${ }^{26}$ T. Spyra, Granice wykładni prawa, Kraków 2006, p. 39. 
2002 - Law of Proceedings before Administrative Courts ${ }^{27}$ since that officer's claim concerns the essence of the legal relationship which connected him with an organ of public administration. There is, therefore, no reason to exclude the jurisdiction of the Administrative Court in matters relating to the "transformation" of a service relationship into an employment relationship ${ }^{28}$.

According to Article 45 (1) of the Polish Constitution, everyone has the right to a just and transparent adjudication of a matter, without unjustifiable delay and by a competent, independent, impartial and free court. Article 77 (2) of the Polish Constitution states that a law cannot prevent access to courts to anyone who wants to pursue his usurped freedoms or rights. The jurisprudence of the Constitutional Tribunal formulates the following elements of the right to a trial:

- access to courts or the right to start proceedings before a court - a body having particular characteristics (independent, impartial, free from political influence),

- the right to an appropriate form of court proceedings consistent with the requirements of justice and transparency,

- the right to a ruling or the right to obtain a binding court decision for a particular matter $^{29}$,

- the right to an appropriate structure and position of organs examining the case $^{30}$.

The Tribunal's jurisprudence indicates that Article 45 (1) of the Polish Constitution formulates the right to a trial positively while Article 77 (2) of the Polish Constitution prohibits blocking access to courts for seeking usurped freedoms and rights determining the scope of acceptable limits of the right to a trial ${ }^{31}$.

According to Article 60 of the Polish Constitution, Polish citizens with full public rights have the right to become public servants on equal terms with all others. In the judgement of the Constitutional Tribunal, the aim of the regulations stipulated in Article 60 of the Polish Constitution is to guarantee that everyone who fulfils the two criteria indicated within it (Polish citizenship and having full public rights) will be treated on equal terms, meaning utilizing the same procedure or,

27 Journal of Laws 2002, No. 153, item 1270.

28 Judgement of the Constitutional Tribunal of 25 February 2002, SK 29/01; judgement of the Constitutional Tribunal of 9 June 1998, K 28/97, OTK 1998, No. 4, item 50; judgement of the Constitutional Tribunal of 10 May 2000, K 21/99, OTK 2000, No. 4, item 109.

${ }^{29}$ Cf. judgement of the Constitutional Tribunal of 9 June 1998, K 28/97, OTK 1998, No. 4, item 50; judgement of the Constitutional Tribunal of 16 March 1999, SK 19/98, OTK ZU 1999, No. 3, item 36; judgement of the Constitutional Tribunal of 27 May 2008, SK 57/06, OTK-A 2008, No. 4 , item 63.

${ }^{30}$ Cf. judgement of the Constitutional Tribunal of 24 October 2007, OTK ZU 2007, No. 9A, item 108 .

${ }^{31}$ Cf. judgement of the Constitutional Tribunal of 9 June 1998, K 28/97, OTK 1998, No. 4, item 50; judgement of the Constitutional Tribunal of 2 April 2001, SK 10/00, OTK 2001, No. 3, item 52. 
more generally, the same rules in the qualifying process. According to Article 60 of the Polish Constitution, the protected right is transparency and public character of rules defining requirements connected to performing public service ${ }^{32}$.

Lack of court protection for officers whose current service relationship is substituted with a form that is less beneficial - an employment relationship, should be seen as a violation of their right to trial. The suggestion that an officer whose service relationship has been changed to an employment relationship can seek his rights at labour court is but an illusion of observing that right ${ }^{33}$. A labour court, by definition, is not an appropriate court when it comes to cases of entering into or the termination of service relationships having a legal and administrative character. This court can judge cases concerning the employment relationship of an employee but fundamentally does not have jurisdiction to assess the establishment and termination of a legal and administrative relationship. Therefore, sending customs officers to labour courts causes the transformation of a service relationship into an employment relationship to slip out of court control. For, in light of current jurisprudence of administrative courts, the acceptance of an offer for employment by a former officer signifies the transformation of a service relationship into an employment relationship making it not an administrative matter ${ }^{34}$. An officer who becomes an employee does not know why in his case the change in employment status from a service relationship to an employment relationship occurred. The acceptance that in these cases administrative courts are not appropriate to settle them, in essence, proclaims the complete arbitrariness of decedents determining which officer's service relationship should be changed to an employment relationship and which one should not.

Therefore, the practice used by customs and revenue service administration of presenting officers with offers for employment is a laconic announcement of the will of the employer. This means than an officer whose relationship is "transformed" is not made familiar with the motivation for the activity of his current employer. Employment of a customs officer using an employment agreement deprives him of his current protection but also removes him from a list of people who are eligible

${ }^{32}$ Constitutional Tribunal in its justification of a judgement of 10 May 2000, K 21/99, OTK 2000, No. 4, item 109.

${ }^{33}$ Decision of the Supreme Administrative Court of 25 July 2019, I OSK 191/18.

34 As indicated in the resolution of the seven judges of the Supreme Administrative Court of 1 July 2019 (I OPS 1/19): "Acceptance of the employment offer by an officer of the Customs and Tax Service and transformation, on the date specified in this proposal, pursuant to Article 171 (1) (2) of the Act of 16 November 2016 - Provisions Introducing the Act on the National Tax Administration (Journal of Laws, item 1948 as amended) of the current service relationship in the preparatory or permanent service in an employment relationship on the basis of an employment contract for an appropriate period of time indefinite or specified, does not imply the obligation of the competent authority to issue a decision on termination of the service relationship". 
for pensions provided to officers. "Transformation" of an officer's relationship can also cause a decrease in salary (commission). Additionally, it also deprives him of current allowances which were the result of his rank or his right to extended vacation time (Article 216 (4) of the Act on the National Fiskal Administration). The numerous complaints of former customs officers about the acts of "transformation" of official relations, submitted to administrative courts, show that they consider the job offers submitted to them as less favourable forms of employment than their previous employment relationship.

\section{REFERENCES}

\section{Literature}

Adamiak B., Zagadnienie domniemania formy decyzji administracyjnej, [in:] Podmioty administracji publicznej i prawne formy ich działania. Studia i materiały z Konferencji Naukowej poświęconej Jubileuszowi 80-tych urodzin Profesora Eugeniusza Ochendowskiego, Torun 2005.

Borkowski J., Zagadnienie kompetencji ogólnej i szczegółowej, „Studia Prawnicze” 1971, nr 31.

Jakimowicz W., Wyktadnia w prawie administracyjnym, Kraków 2006.

Jaśkiewicz W., Pracownicy administracji, [in:] System Prawa Administracyjnego, red. J. Jendrośka, t. 2, Wrocław 1977.

Kiełkowski T., Sprawa administracyjna, Kraków 2004.

Kuczyński T., Pojęcie i przedmiot prawa stosunków służbowych, [in:] System Prawa Administracyjnego, t. 11: Stosunek stużbowy, red. R. Hauser, Z. Niewiadomski, A. Wróbel, Warszawa 2011.

Kuczyński T., Właściwość sądu administracyjnego w sprawach stosunków stużbowych, Wrocław 2002. Pieprzny S., Organy bezpieczeństwa i porządku publicznego w prawie administracyjnym, Rzeszów 2007.

Spyra T., Granice wykładni prawa, Kraków 2006.

Szustakiewicz P., Stosunki służbowe funkcjonariuszy stu̇̇b mundurowych i żotnierzy zawodowych jako sprawa administracyjna, Warszawa 2012.

Wieczorek M., Charakter prawny stosunków stużbowych funkcjonariuszy stużb mundurowych, Toruń 2017.

Zieliński T., Podstawowe problemy prawa stużby państwowej, „Państwo i Prawo” 1982, z. 9.

Zimmermann J., Polska jurysdykcja administracyjna, Warszawa 1996.

\section{Legal acts}

Act of 30 August 2002 - Law of Proceedings before Administrative Courts (Journal of Laws 2002, No. 153 , item 1270).

Act of 16 November 2016 on the National Fiscal Administration (Journal of Laws, item 1947).

Act of 16 November 2016 - Provisions Introducing the Act on the National Tax Administration (Journal of Laws, item 1948 as amended). 


\section{Case law}

Decision of the Supreme Administrative Court of 25 July 2019, I OSK 191/18.

Judgement of the Constitutional Tribunal of 9 June 1998, K 28/97, OTK 1998, No. 4, item 50.

Judgement of the Constitutional Tribunal of 16 March 1999, SK 19/98, OTK ZU 1999, No. 3, item 36. Judgement of the Constitutional Tribunal of 14 December 1999, SK 14/98, OTK ZU 1999, No. 7 , item 163.

Judgement of the Constitutional Tribunal of 10 May 2000, K 21/99, OTK 2000, No. 4, item 109. Judgement of the Constitutional Tribunal of 2 April 2001, SK 10/00, OTK 2001, No. 3, item 52. Judgement of the Constitutional Tribunal of 25 February 2002, SK 29/01.

Judgement of the Constitutional Tribunal of 27 January 2003, SK 27/02, OTK ZU 2003, No. 1A, item 2.

Judgement of the Constitutional Tribunal of 19 October 2004, K 1/04, OTK ZU 2004, No. 9A, item 93. Judgement of the Constitutional Tribunal of 14 June 2005, P 18/03, OTK ZU 2005, No. 6A, item 63. Judgement of the Constitutional Tribunal of 24 October 2007, OTK ZU 2007, No. 9A, item 108. Judgement of the Constitutional Tribunal of 27 May 2008, SK 57/06, OTK-A 2008, No. 4, item 63. Judgement of the Supreme Administrative Court in Wrocław of 31 August 1984, SA/Wr 430/84, OSP 1986, No. 9-10, item 176.

Judgement of the Supreme Administrative Court of 8 February 2019, I OSK 1744/18.

Judgement of a Voivodeship Administrative Court in Warsaw of 5 December 2017, VII SA/Wa $2741 / 16$.

Resolution of the seven judges of the Supreme Administrative Court of 1 July 2017, I OPS 1/19.

\section{STRESZCZENIE}

Artykuł dotyczy ,przekształcenia” stosunku służbowego funkcjonariusza uprzednio zatrudnionego w służbie celnej w stosunek pracy. Owo przekształcenie odbywało się na podstawie ustaw reformujących administrację celno-skarbową, które weszły w życie w 2016 r. Według utrwalonej już linii orzecznictwa sądów istota „przekształcenia” polega na tym, że funkcjonariusz pełniący służbę na podstawie stosunku administracyjnoprawnego wskutek oferty złożonej przez pracodawcę staje się pracownikiem. Przekształcenie stosunku służbowego w stosunek pracy odbywa się zatem bez uprzedniego wygaszenia stosunku służbowego w drodze aktu administracyjnego.

Słowa kluczowe: stosunek służbowy funkcjonariuszy służb mundurowych 